\title{
Cyclin D1 amplification and expression in human breast carcinoma: correlation with histological prognostic markers and oestrogen receptor expression
}

\author{
S D Worsley, B A Jennings, K H Khalil, M Mole, A C Girling
}

\begin{abstract}
Aims-To study the amplification of the Cyclin D1 gene (CCND1) in human breast carcinoma; to relate this to Cyclin D1 protein expression; to relate these parameters to recognised pathological prognostic factors, including oestrogen receptor (ER) status.

Methods-DNA extracted from frozen sections of breast tumours $(n=36)$ was used for Southern blotting. Probes for CCND1, c-myc and the immunoglobulin heavy chain locus (IgH) were hybridised to tumour DNA. Immunocytochemical expression of Cyclin D1 protein and ER was studied in paraffin wax sections from the same tumours.

Results-Amplification of CCND1 was observed in $11 \%$ (four of 36 ) of tumours studied. Over expression of Cyclin D1 protein was observed in $73 \%(30 / 41)$ of tumours. There was no correlation between recognised histological prognostic markers and either gene amplification or expression. However, a weak association was seen between Cyclin D1 expression and ER status.

Conclusions-A disparity exists between locus amplification and over expression of Cyclin D1, suggesting the existence of another mechanism for raised protein expression. No significant correlation was detected between either Cyclin D1 amplification or over expression and established prognostic markers.

(f Clin Pathol: Mol Pathol 1996;49:M46-M50)
\end{abstract}

Molecular Genetics Department, Norfolk and Norwich NHS Healthcare Trust, Brunswick Road, Norwich NR1 3SR S D Worsley B A Jennings

Department of Surgery

K H Khalil

Histopathology

Department

$M$ Mole

A C Girling

Correspondence to: Dr S Worsley.

Accepted for publication 10 October 1995
Keywords: breast cancer, prognosis, Cyclin D1 gene.

There is a continual search for new prognostic markers in human breast cancer which may refine the selection of patients for particular treatment regimes.

Cyclins are proteins which are involved in the control of the cell cycle. ${ }^{1}$ One such protein, Cyclin D1, has a role in the control of the transition between $G 1$ and $S$ phase in the cell cycle. ${ }^{2}$ High expression of Cyclin D1 is observed during $\mathrm{G} 1$ followed by low expression during $S$ phase. ${ }^{34}$ Deregulated expression of Cyclin D1 causes abnormalities in growth control, resulting in a decrease in the duration of G1..$^{56}$
The gene encoding Cyclin D1, termed CCND1, D11S287 or PRAD1, is located on band $\mathrm{q} 13$ of chromosome $11,{ }^{7}$ and has potential as an oncogene ${ }^{8-10}$ Accumulating evidence suggests that CCND1 is the $b c l-1$ gene. ${ }^{112}$ Structural abnormalities affecting this band have been reported in a variety of human tumours, including parathyroid neoplasia, ${ }^{7}$ centrocytic lymphomas, ${ }^{13}$ oesophageal carcinomas, ${ }^{1415}$ and squamous and breast carcinomas. ${ }^{1617} \mathrm{~A}$ number of different types of abnormalities have been reported, including DNA deletions, ${ }^{18}$ translocations ${ }^{1920}$ and amplifications. ${ }^{21} \mathrm{Am}$ plification occurs in $10-20 \%$ of primary breast tumours $^{822-24}$ and has been associated with a subgroup of primary breast tumours that have an unexpectedly poor prognosis. ${ }^{2325-27} \mathrm{Al}-$ though other genes are frequently co-amplified with CCND1 - for example, int- $2,^{2829} H S T 1,{ }^{30}$ $E M S 1,{ }^{31}$ and Gst $\mathrm{pi}^{32}{ }^{32}$ it has been suggested that amplification of a gene close to int-2 and $H S T 1$ may result in a subset of ER positive tumours with poor prognosis. Amplication of CCND1 may be the selective force on the $11 \mathrm{q} 13$ amplicon that is actually providing a growth advantage in breast tumours. ${ }^{821}$

Expression of the Cyclin D1 protein has been studied in breast tumours only recently. One study suggests that over expression of this protein may occur in the absence of gene amplification. ${ }^{33}$

In this study, we have related gene amplification and protein expression to recognised prognostic markers, including tumour size and grade, axillary lymph node status and ER status. It is hoped that this may assist in the elucidation of the role of this gene in the pathogenesis of breast cancer.

\section{Methods}

Samples from 41 women treated surgically for primary breast carcinoma were included in the study. Their mean age was 60 years (range 35-80 years). None of the patients had received preoperative chemotherapy.

Tumour samples were obtained both from mastectomy and excision biopsy specimens which had been sent fresh to the histopathology laboratory. On receipt, areas of tumour were identified macroscopically by a pathologist and a representative $10-15 \mathrm{~mm}$ sample selected for molecular biology studies. This was then snap frozen in liquid nitrogen and stored at $-80^{\circ} \mathrm{C}$. The remainder of the tumour was processed 
for histopathological examination according to routine laboratory protocols. Preoperative blood samples $(10 \mathrm{ml})$ were available for 10 patients.

\section{MOLECULAR BIOLOGY}

Tumour samples were removed from the $-80^{\circ} \mathrm{C}$ freezer and cut in a cryostat at $-20^{\circ} \mathrm{C}$. Haematoxylin and eosin stained sections cut at three levels were examined to confirm the presence and amount of tumour in each sample. To qualify for inclusion in the study a minimum of $70 \%$ of the tissue volume had to consist of tumour cells.

Sixty serial $10 \mu \mathrm{m}$ sections were cut from each tumour sample. Following the addition of lysis buffer, each was incubated with 50 units proteinase $\mathrm{K}$ at $37^{\circ} \mathrm{C}$ for one hour. DNA was extracted using a standard phenol chloroform protocol on an automated nucleic acid purification system (341 Applied Biosystems, Warrington, UK).

Digestion of DNA from frozen sections of tumour with the restriction endonuclease Pst 1 was followed by Southern blotting. ${ }^{34}$ Digests of DNA extracted from peripheral blood were used as controls.

DNA on the blot was then hybridised to probes labelled by the random priming method. ${ }^{35}$ The CCND1 probe was a 0.8 kilobase EcoR1-Xho1 genomic DNA fragment derived from the probe designated " $\mathrm{B}$ " by $\mathrm{Ar}$ -

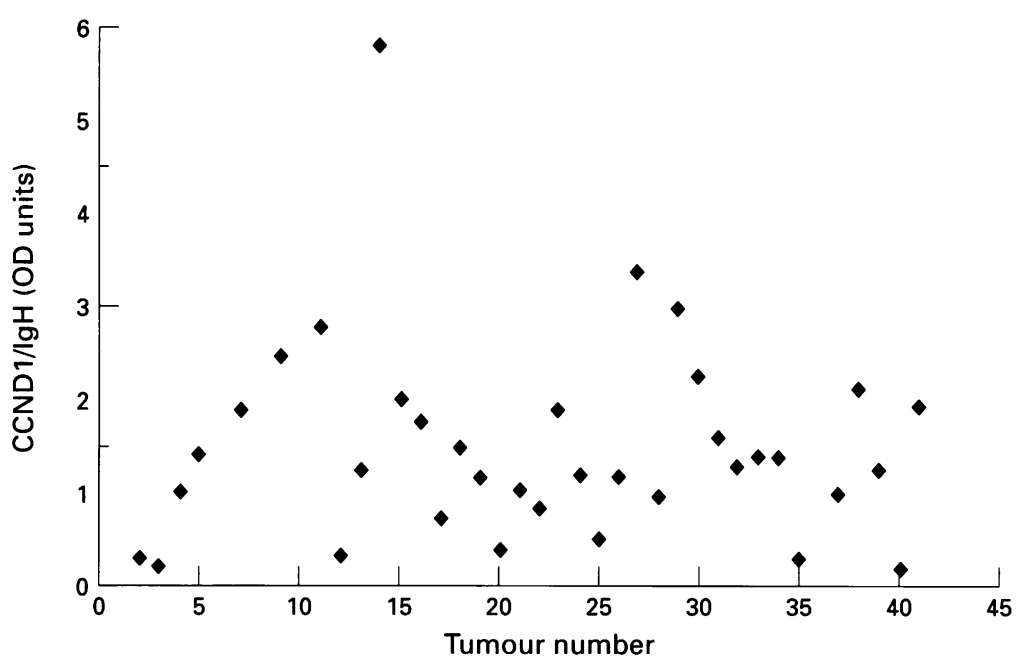

Figure 1 CCND1 amplification in primary breast carcinoma. The ratio of optical density (OD) readings for hybridisation of the CCND1 and IgH probe is shown for each tumour. Four tumours show amplification with values above the normal range.

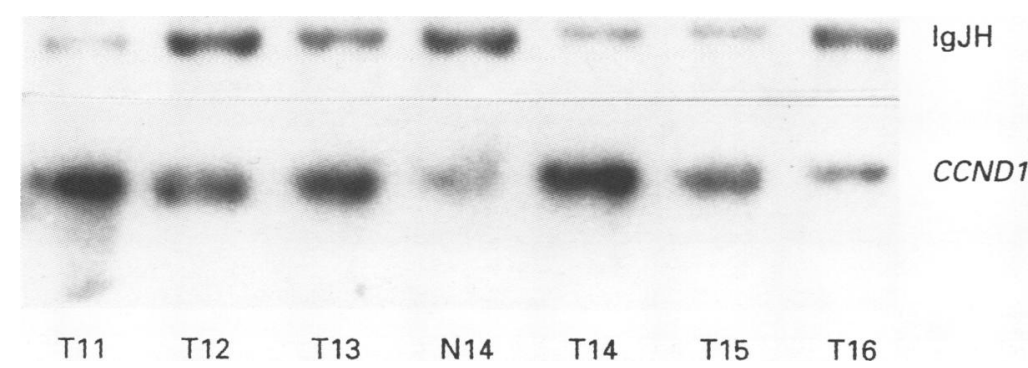

Figure 2 Autoradiograph of a Southern blot hybridised with the probe for CCND1 and then stripped and probed with the IgH probe. Amplification of CCND1 is seen in DNA from tumour numbers T11 and T14. nold et al (a gift from the Imperial Cancer Research Fund Laboratories, Lincolns Inn Fields, London). The c-myc probe was a 1.4 kilobase Cla1-EcoR1 fragment covering exon 3 at the $3^{\prime}$ end of the c-myc gene. A probe for immunoglobulin $\mathrm{JH}$ chain was used as a control for DNA loading.

Autoradiographs were produced by exposure to a piece of pre-flashed Hyperfilm-TM (Amersham, Little Chalfont, UK) for two to seven days at $80^{\circ} \mathrm{C}$. The optical density readings of each probe binding to lymphocyte DNA from patient blood was measured. From this, an average ratio of CCND1 and c-myc to IgJH chain probe was calculated. The normal range was defined as the average ratio $\pm 2 \mathrm{SD}$. Values above this range were regarded as representive of gene amplification.

\section{IMMUNOCYTOCHEMISTRY}

Representative sections selected from each tumour were mounted on APES ( $2 \% 3^{\prime}$-aminopropyltriethoxysilane) coated slides and high pressure antigen retrieval was used. ${ }^{36}$

A monoclonal antibody directed against $\mathrm{Cy}$ clin D1 (a gift from Dr Jiri Bartek, Danish Cancer Society) was used at a dilution of 1 in 2000 in phosphate buffered saline at $\mathrm{pH} 7 \cdot 4$ overnight. ${ }^{33}$ A commercially available monoclonal antibody directed against human oestrogen receptor (Dako-ER1D5; Dako, High Wycombe, UK) was used at a dilution of 1 in 100 in Tris buffered saline at $\mathrm{pH} 7 \cdot 2$ for one hour. The indirect avidin-biotin immunoperoxidase technique was used to demonstrate antibody binding sites. Negative (primary antibody excluded) and positive controls (test slides supplied with antibody) were included with each batch of slides stained.

All cases were assessed independently by two pathologists and any difference of opinion on initial evaluation was resolved by subsequent discussion.

\section{HISTOPATHOLOGY}

Histopathological assessment of haematoxylin and eosin stained tumour sections included the following parameters: tumour type, grade and size, the presence or absence of vascular invasion, and the degree of lymphocytic infiltration. Haematoxylin and eosin stained sections of lymph nodes received with tumour samples were also examined for metastases.

\section{Results}

\section{MOLECULAR BIOLOGY}

Samples taken from 36 of tumours in the study contained sufficient malignant cells for Southern blotting. Amplification of CCND1 was demonstrated in four $(11 \%)$ of these, with a two- to fivefold increase in gene copy number for these tumours (figs 1 and 2).

The number of tumours showing c-myc amplification in this study was 33\% (12/36). Fisher's exact test $(p>0.4)$ shows that this value is in agreement with other studies. ${ }^{37}$ 
IMMUNOCYTOCHEMISTRY

Pressure cooker antigen retrieval resulted in even, reproducible staining with good morphological preservation. No inappropriate staining was observed in negative controls and there was appropriate staining in positive controls.

Cyclin D1 staining was predominantly nuclear and varied in intensity. Although cytoplasmic staining was observed in some cases, this was rarely found without associated nuclear staining.

On initial evaluation, 28/41 (68\%) tumours in the study strongly expressed Cyclin D1.
Tumours with very weak staining, with only occasional positive nuclei or with a perinuclear pattern of staining, were classified as negative (five $/ 41,12 \%$ ). An intermediate level of staining was observed in eight/41 (20\%) tumours. After further evaluation, two of these cases were classified as positive and six as negative.

In total, therefore, $30 / 41(73 \%)$ tumours were considered to have significantly high expression of Cyclin D1 protein and so were classified as positive. Fisher's exact test $(p>0 \cdot 4)$ shows that this number of positive tumours is in agreement with other studies. ${ }^{338}$ Representative staining patterns are illustrated in fig 3.
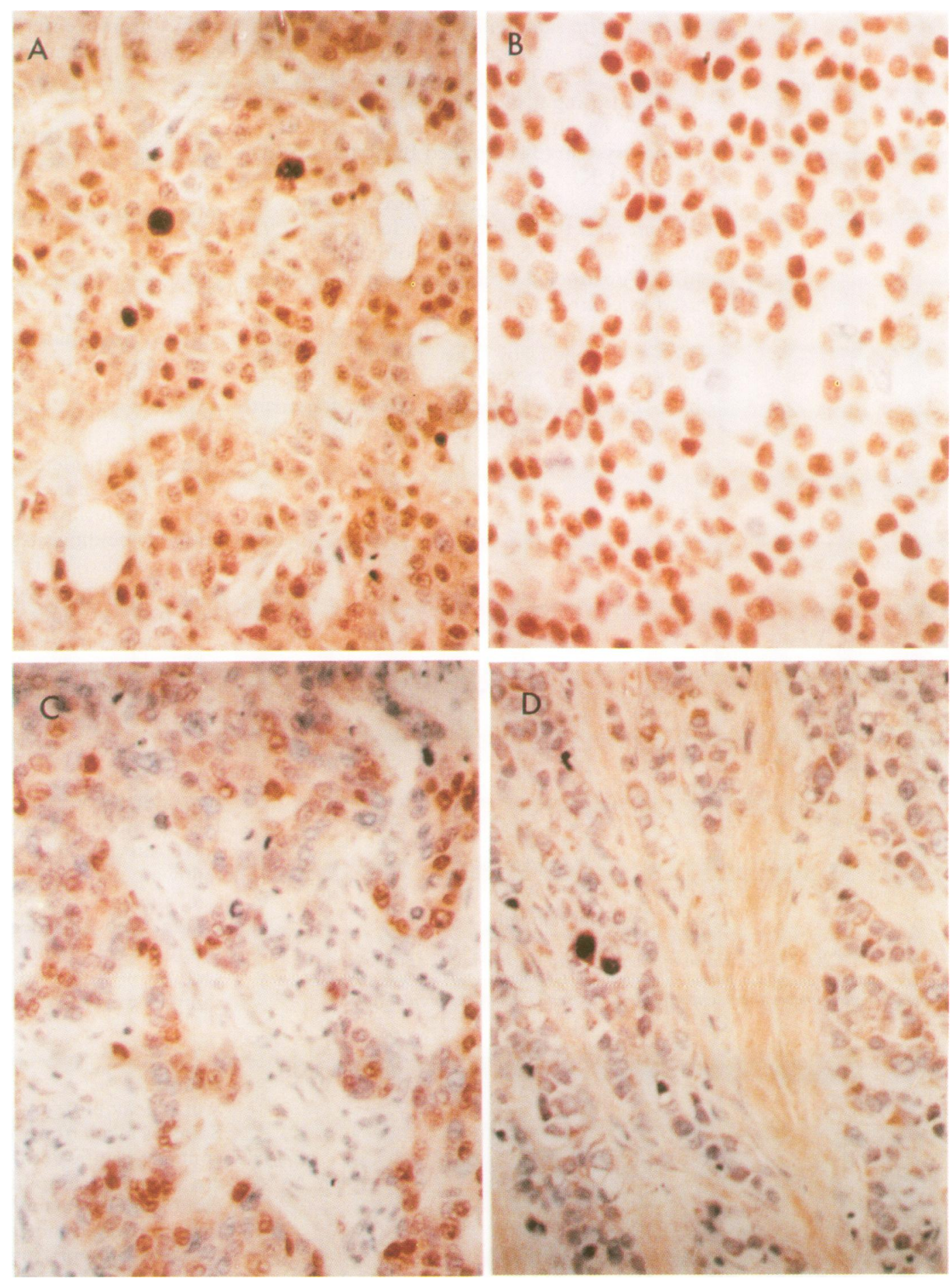

Figure 3 Immunocytochemical demonstration of Cyclin D1 and ER in breast tumour tissue. A, Strong nuclear expression of Cyclin D1 $(\times 100) ; B$, strong nuclear expression of ER in a section from the same tumour $(\times 150) ; C$, intermediate expression of Cyclin D1 subsequently classified as positive $(\times 100) ; D$, weak cytoplasmic expression of Cyclin D1 classified as negative $(\times 100)$. 
Tumour stage and grade

\begin{tabular}{ll}
\hline Tumour type & Number of tumours \\
\hline Ductal & \\
grade 1 & 4 \\
grade 2 & 14 \\
grade 3 & 18 \\
Lobular & 4 \\
Special type & 1 \\
\hline
\end{tabular}

OESTROGEN RECEPTOR EXPRESSION

Positive staining for ER was observed in 24/41 (59\%) tumours (fig 3B) indicating that tumour sampling was representative of a normal tumour cell population (Fisher's exact test $\mathrm{p}>0 \cdot 48) .{ }^{39}$

\section{HISTOPATHOLOGY}

The tumours ranged in size from 0.7 to $10 \mathrm{~cm}$ (mean $3.5 \mathrm{~cm}$ ). The table summarises tumour type and grade. Vascular invasion was identified in 13 cases and nodal metastases in 20 .

RELATION OF CCND1 AMPLIFICATION AND CYCLIN D1 EXPRESSION TO PROGNOSTIC FACTORS

No significant relation between either CCND1 amplification or Cyclin D1 expression and histopathological prognostic markers was identified.

RELATION OF CCND1 AMPLIFICATION AND CYCLIN DI EXPRESSION AND ER STATUS Three of the four tumours showing CCND1 amplification also showed high ER expression. Cyclin D1 expression showed a weak correlation with ER status (correlation coefficient $+0 \cdot 3)$.

\section{Discussion}

This study has shown that there is a disparity between amplification of CCND1 and expression of its protein product, Cyclin D1. Immunocytochemical staining has revealed cases where there is high expression of Cyclin D1 in the absence of any measurable change in DNA copy number; in fact only $6 \%$ of the tumours over expressing Cyclin D1 have associated gene amplification. This disparity between gene amplification and expression is in agreement with other recent reports. ${ }^{338} \mathrm{We}$ conclude that an unidentified mechanism is operating in some tumours to cause increased protein expression. Possibile mechanisms include alterations to the gene promoter region or altered expression of a regulatory transcription factor, such as c-jun. ${ }^{40} \mathrm{~A}$ longer mRNA halflife would result in the production of more active protein without the necessity for an increased gene copy number or increased transcription. A report on the existence of a truncated Cyclin D1 gene encoding a stable $1 \cdot 1-1 \cdot 3$ kilobase mRNA in a human breast cancer cell line suggests that this short message is more stable than the normally dominant $4 \cdot 2$ kilobase transcript. ${ }^{41}$ Whatever the mechanism may be, deregulated expression of this cell cycle controlling protein is likely to provide a selective growth advantage in tumours.

In common with other immunocytochemical studies some subjectivity exists in the interpretation of Cyclin D1 staining. This is compounded by the lack of agreement as to how different staining patterns should be classified. Gillett et $a l^{33}$ subdivided Cyclin D1 staining into four categories: weak (57\%), moderate $(13 \%)$, strong (17\%), and very strong (13\%). Zhang $e t a l^{88}$ used three staining categories: positive $(28 \%)$, moderate $(53 \%)$, or negative $(19 \%)$. Staining for Cyclin D1 is in its infancy and more work is needed to clarify the significance of intermediate staining patterns.

In this study neither CCND1 amplification nor protein expression seemed to be related to known histological prognostic markers. This may be because of the small number of tumour samples studied. There was, however, a weak association between Cyclin D1 expression and high ER expression. This supports the hypothesis that over expression of Cyclin D1 may define a subgroup of ER positive tumours that have an unexpectedly poor prognosis. ${ }^{23}$

In the future the classification of tumours on the basis of their pattern of genetic alterations may add to currently established markers and enable refinement of existing classifications. This would have an immediate impact on patient care and may also lead to the use of treatments whose design is based on the biological consequences of gene mutations. An important step towards this goal is the development of a fuller understanding of how genetic alterations and the expression of gene products relate to the development of the malignant phenotype.

We would like to thank the Big "C" Appeal and the Norfolk and Norwich Bicentenary Trust, who jointly funded the project. We are also grateful to Drs V Fantl and G Peters of the Imperial Cancer Research Fund Laboratories, Lincolns Inn Fields, London, for the gift of the CCND1 probe, Dr J Bartek of the don, for the gift of the CCND1 probe, Dr J Bartek of the
Danish Cancer Society for the Cyclin D1 antibody and Drs E Danish Cancer Society for the Cyclin D1 antibody and Drs E
Rytina and L Perry for their assistance in assessing immunocytochemical staining.

1 Hunt T. Cyclins and their partners: from a simple idea to a complicated reality. Semin Cell Biol 1991;2:213-22.

Baldin V, Lukas J, Marcote MJ, Pagano M, Draetta G. Cyclin D1 is a nuclear protein required for cell cycle progression in G1. Genes Dev 1993;7:812-21.

3 Reed SI. The role of p34 kinases in the G1 to S-phase transition. Annu Rev Cell Biol 1992;8:529-61.

4 Lukas J, Pagano M, Staskova Z, Draetta G, Bartek J. Cyclin D1 protein oscillates and is essential for cell cycle progression in human tumour cell lines. Oncogene 1994; 9:707-18.

5 Jiang W, Khan SM, Zhou P, Zhang YJ, Cacace AM, Infante AS. Overexpression of cyclin D 1 in rat fibroblasts causes abnormalities in growth control, cell cycle progression and abnormalities in growth control, cell cycle progre

6 Musgrove EA, Lee CS, Buckley MF, Sutherland RL. Cyclin $\mathrm{D} 1$ induction in breast cancer cells shortens $\mathrm{Gl}$ and is sufficient for cells arrested in G1 to complete the cell cycle. Proc Natl Acad Sci USA 1994;91:8022-6.

7 Arnold A, Kim HG, Gaz RD, Eddy RL, Fukusima Y, Kronenberg HM. Molecular cloning and chromosoma mapping of DNA rearranged with the parathyroid hormone gene in a parathyroid adenoma. F Clin Invest 1989 ; 83:2034-40.

8 Lammie GA, Fantl V, Smith R. D11S287, a putative oncogene on chromosome 11q13, is amplified and expressed . to $\mathrm{BCL}-1$. Oncogene 1991;6:439-44.

9 Buckley MF, Sweeney KJE, Hamilton JA, Sini RL, Manning $\mathrm{DL}$, Nicholson RI, et al. Expression and amplification of cyclin genes in human breast cancer. Oncogene 1993;8: cyclin gen $2127-33$.

10 Lovec H, Sewing A, Lucibello F, Muller R, Moroy T. Oncogenic activity of cyclin D1 revealed through co- 
operation with Ha-ras: link between cell cycle control and malignant transformation. Oncogene 1994;9:323-6.

11 Rosenberg CL, Wong E, Petty EM, Bale AE, Tsujimoto Y, Harris NL, et al. PRAD 1, a candidate BCLl oncogene: mapping and expression in centrocytic lymphoma. Proc mapping and expression in centrocytic

12 Komatsu H, Iida S, Yamamoto K, Mikuni C, Nitta M, Takahashi $\mathrm{T}$, et al. A variant chromosome translocation at $11 \mathrm{q} 13$ identifying PRAD1/Cyclin D1 as the BCL-1 gene. Blood 1994;84:1226-31.

13 Williams ME, Swerdlow SH, Rosenberg CL, Arnold A. Centrocytic lymphoma: a B-cell non-Hodgkin's lymphoma characterized by chromosome $11 \mathrm{bcl}-1$ and PRAD 1 rearrangements. Curr Top Microbiol Inmunol 1992;182 $325-9$

14 Jiang W, Kahn SM, Tomita N, Zhang YJ, Lu SH, Weinstein IB. Amplification and expression of the human cyclin D IB. Amplification and expression of the human cyclin D

15 Yoshida T, Sakamoto H, Terada M. Amplified genes in cancer in upper digestive tract. Semin Cancer Biol 1993; 4:33-40.

16 Brookes S, Lammie GA, Schuuring E, Dickson C, Peters $\mathrm{G}$. Linkage map of a region of human chromosome band $11 \mathrm{q} 13$ amplified in breast and squamous cell tumors. Genes Chromosom Cancer 1992;4:290-301.

17 Klijanienko J, Bianchi AB, Cvitkovic E, Janot F, Luboinsk B, Conti CJ. Unexpected Prad-1 amplification in multiple simultaneous localisations of squamous cell ca simultaneous localisations of squamous cell carcinoma of

18 Thakker RV, Bouloux P, Wooding C, Chotai K, Broad PM, Spurr NK, et al. Association of parathyroid tumours in multiple endocrine neoplasia type 1 with loss of alleles on multiple endocrine neoplasia type 1 with loss of alles

19 Iida S, Seto M, Yamamoto K, Ueda R. Overexpression of $\mathrm{PRAD} 1$ gene in B-cell malignancy with $\mathrm{t}(11 ; 14)(\mathrm{q} 13 ; \mathrm{q} 32)$ translocation. Nippon Rinsho 1992;50:1374-9.

20 Seto M, Yamamoto K, Iida S. Gene rearrangement and overexpression of PRAD1 in lymphoid malignancy with $\mathrm{t}(11 ; 14)(\mathrm{q} 13 ; \mathrm{q} 32)$ translocation. Oncogene 1992;7:1401-6.

21 Dickson C, Fantl V, Gillett C, Brookes S, Bartek J, Smith $\mathrm{R}$, et al. Amplification of chromosome band $11 \mathrm{q} 13$ and a role for cyclin D1 in human breast cancer. Cancer Lett 1995;90:43-50.

22 Lammie GA, Peters G. Chromosome 11q13 abnormalities in human cancer. Cancer Cells 1991;3:413-19.

23 Fantl V, Richards MA, Smith R. Gene amplification on chromosome band $11 \mathrm{q} 13$ and oestrogen receptor status in breast cancer. Eur f Cancer 1990;26:423-9.

24 Champème MH, Bieche I, Lizard S, Lidereau R. 11q13 amplification in local recurrence of human primary breas cancer. Genes Chromosom Cancer 1995;12:128-33.

25 Schuuring E, Verhoeven E, van-Tinteren H, Peterse JL, Nunnink B, Thunnissen FB, et al. Amplification of genes within the chromosome $11 \mathrm{q} 13$ region is indicative of poor prognosis in patients with operable breast cancer. Cancer prognosis in patients $1992 ; 52: 5229-34$.

26 Borg A, Sigurdsson H, Clark GM, Ferno M, Fuqua SA Olsson H, et al. Association of INT2/HST1 co-amp- lification in primary breast cancer with hormone-dependent phenotype and poor prognosis. Br f Cancer 1991 63:136-42.

27 Henry JA, Hennessy C, Levett DL, Lennard TW, Westley BR, May FE. int-2 amplification in breast cancer: as sociation with decreased survival and relationship to amplification of c-erbB-2 and c-myc. Int 7 Cancer 1993;53. 774-80.

28 Tanigami A, Tokino T, Takita K, Ueda M, Kasumi F, Nakamura Y. Detailed analysis of an amplified region at chromosome 11q13 in malignant tumors. Genomics 1992; 13:21-4.

29 Lidereau R, Callahan R, Dickson C, Peters G, Escot C. Amplification of the int-2 gene in primary human breast tumours. Oncogene Res 1988;2:285-91.

30 Goldfarb M, Deed R, MacAllan D, Walther W, Dickson C, Peters G. Chromosomal localisation of the hst oncogene and its co-amplication with the int- 2 oncogene in a human and its co-amplication with the int-2 onc

31 Brookes S, Lammie GA, Schuuring E, de Boer C, Michalides R, Dickson C, et al. Amplified region of chromosome band $11 \mathrm{q} 13$ on breast and squamous cell carcinomas encompasses three $\mathrm{CpG}$ islands telomeric of FGF3, including the expressed gene EMS1. Genes Chromosom Cancer 1993;6:222-31.

32 Saint-Ruf C, Malfoy B, Scholl S, Zafrani B, Dutrillaux B. GST pi gene is frequently co-amplified with INT2 and HSTF1 proto-oncogenes in human breast cancers. Oncogene 1991;6:403-6.

33 Gillett C, Fantl C, Smith R, Fisher C, Bartek J, Dickson $\mathrm{C}$, et al. Amplification and overexpression of cyclin D 1 in $\mathrm{C}$, et al. Amplification and overexpression of cyclin D in Cancer Res 1994;54:1812-17.

34 Southern EM. Detection of specific sequences among DNA fragments separated by gel electrophoresis. $7 \mathrm{Mol}$ Biol 1975;98:503-7.

35 Feinberg AP, Vogelstein B. A technique for radiolabelling DNA restriction endonuclease fragments to high specific activity. Anal Biochem 1984;137:266-72.

36 Norton AJ, Jordan S, Yeomans P. Brief, high-temperature heat denaturation (pressure cooking): A simple and effective method of antigen retrieval for routinely processed tissues. F Clin Pathol 1994;173:371-9.

37 Escot C, Theillet C, Lidereau R. Genetic alteration of the cmyc proto-oncogene in human primary breast carcinomas. myc proto-oncogene in human primary breast

38 Zhang SY, Camamano J, Cooper F, Klein-stzanto A. Immunohistochemistry of cyclin D1 in human breast cancer. Am $\mathcal{F}$ Clin Pathol 1994;102:695-8.

39 Brown M. Estrogen receptor molecular biology. Hematol Oncol Clin North Am 1994;8:101-11.

40 Herber B, Truss $M$, Beato $M$, Muller R. Inducible regulatory elements in the human cyclin D1 promoter. Oncogene 1994;9:1295-304.

41 Lebwohl DE, Muise-Helmericks R, Sepp-Lorenzino L, Serve S, Timaul M, Bol R, et al. A truncated cyclin D1 gene encodes a stable mRNA in a human breast cancer cell line. Oncogene 1994;9:1925-9. 